\section{Heart cells: no longer undivided}

\section{By Michael J. Haas, Senior Writer}

The inability of adult heart cells to divide rapidly enough to repair cardiac damage has been a major impediment to regenerating heart tissue and preventing fibrosis after myocardial infarction. Now, a U.S. team has used cyclin $A 2$ gene therapy to induce cardiomyocyte division and improve heart function in pig models of myocardial infarction. ${ }^{1}$

The technology has been licensed to VentriNova Inc., which is planning IND-enabling studies and is seeking investors to fund clinical testing of cyclin A2 (CCNA2) gene therapy to treat MI.

Most mammalian cells regenerate their tissues after injury by undergoing mitosis, but cardiomyocytes do not. Instead, cardiac fibroblasts proliferate after MI. Although they replace the damaged tissue and thus maintain the organ's structural integrity, ${ }^{2,3}$ they result in fibrotic scarring that compromises heart function and can lead to heart failure.

In the 1990s, studies by multiple groups showed that CCNA2 regulated the cell cycle transitions required for mitosis in many mammalian cell types ${ }^{4,5}$ but was silenced in mammalian cardiomyocytes shortly after birth. ${ }^{6}$ Clinical studies have shown that cardiomyocytes undergo a limited degree of turnover-a process by which mitotic cells replace older ones-across the human lifespan. ${ }^{7,8}$

The unanswered question was whether CCNA2 in adult cardiomyocytes could be reactivated to regenerate heart tissue.

Answers started to emerge in 2004, when a group led by Debra Wolgemuth at Columbia University Medical Center engineered mouse embryos to keep Ccna2 active in the heart after birth. The team observed significant cardiomyocyte mitosis in the postnatal mice well into adulthood. ${ }^{9}$

These findings led Hina Chaudhry, a postdoctoral fellow in Wolgemuth's group and first author on the mouse study, to investigate whether cardiomyocytes in the engineered mice could repair heart damage after MI.

Three years later, Chaudhry showed that the engineered mice regenerated heart tissue through cardiomyocyte mitosis. ${ }^{10}$ Subsequently, another team led by Chaudhry showed that in wild-type rat models of MI, an adenoviral vector encoding mouse Ccna2 increased cardiac function and the density of heart muscle tissue and decreased cardiac fibrosis compared with empty vector. ${ }^{11}$

Wolgemuth is a professor of genetics and development at the Columbia University Medical Center. Chaudhry is now an associate professor of medicine and director of cardiovascular regenerative medicine at the Icahn School of Medicine at Mount Sinai.

For the current study, Chaudhry's team at Mount Sinai-along with a

Table 1. Cardiovascular expressions. At least 10 companies have gene therapies in preclinical through Phase III development to treat a range of cardiovascular indications. The majority of the gene therapies act by promoting angiogenesis or improving the function of existing heart cells. Only one therapy - VN-100 from VentriNova Inc. - regenerates heart tissue by promoting the proliferation of existing cardiomyocytes.

Source: BCIQ: BioCentury Online Intelligence

\begin{tabular}{|c|c|c|c|c|}
\hline Company & Product & Description & Indication(s) & Status \\
\hline $\begin{array}{l}\text { Cardium Therapeutics Inc. } \\
\text { (OTCQB:CRXM) }\end{array}$ & $\begin{array}{l}\text { Generx alferminogene } \\
\text { tadenovec (Ad5FGF4) }\end{array}$ & $\begin{array}{l}\text { Adenoviral vector encoding fibroblast } \\
\text { growth factor } 4 \text { (FGF4) }\end{array}$ & $\begin{array}{l}\text { Coronary artery disease (CAD); } \\
\text { ischemia/reperfusion injury }\end{array}$ & Phase III \\
\hline $\begin{array}{l}\text { Vical Inc. (NASDAQ:VICL); AnGes } \\
\text { MG Inc. (Tokyo:4563); Daiichi Sankyo } \\
\text { Co. Ltd. (Tokyo:4568); Mitsubishi } \\
\text { Tanabe Pharma Corp. (Tokyo:4508) }\end{array}$ & $\begin{array}{l}\text { Collategene } \\
\text { beperminogene } \\
\text { perplasmid (AMG0001; } \\
\text { HGF gene therapy) }\end{array}$ & $\begin{array}{l}\text { Plasmid encoding human hepatocyte } \\
\text { growth factor/scatter factor (HGF/SF) }\end{array}$ & $\begin{array}{l}\text { Advanced peripheral artery disease } \\
\text { (PAD); ischemia/reperfusion injury }\end{array}$ & Phase III \\
\hline \multirow{2}{*}{$\begin{array}{l}\text { Celladon Corp. (NASDAQ:CLDN); } \\
\text { AmpliPhi Biosciences Corp. } \\
\text { (OTCBB:APHB) }\end{array}$} & \multirow{2}{*}{$\begin{array}{l}\text { Mydicar (AAV1/ } \\
\text { SERCA2a) }\end{array}$} & \multirow{2}{*}{$\begin{array}{l}\text { Recombinant adeno-associated viral } \\
\text { (AAV) vector encoding ATPase } \mathrm{Ca}^{++} \\
\text {transporting cardiac muscle slow } \\
\text { twitch } 2(A T P 2 A 2 ; \text { SERCA2A) }\end{array}$} & Heart failure & Phase IIb \\
\hline & & & $\begin{array}{l}\text { Advanced heart failure in patients } \\
\text { with a left ventricular assist device } \\
\text { (LVAD); diastolic heart failure; } \\
\text { pulmonary arterial hypertension } \\
\text { (PAH); arteriovenous fistula } \\
\text { maturation failure in dialysis } \\
\text { patients }\end{array}$ & Preclinical \\
\hline \multirow[t]{2}{*}{ ViroMed Co. Ltd. (KOSDAQ:084990) } & \multirow[t]{2}{*}{ VM202 } & \multirow{2}{*}{$\begin{array}{l}\text { Proprietary } \mathrm{pCK} \text { vector encoding } \\
\text { engineered } H G F / S F\end{array}$} & Ischemia/reperfusion injury & Phase II \\
\hline & & & $\mathrm{CAD}$ & Phase I/II \\
\hline VentriNova Inc. & VN-100 & $\begin{array}{l}\text { Adenoviral vector encoding cyclin } A 2 \\
\text { (CCNA2) }\end{array}$ & Myocardial infarction (MI) & Preclinical \\
\hline NanoCor Therapeutics Inc. & Carfostin & $\begin{array}{l}\text { Protein phosphatase } 1 \text { regulatory } \\
\text { inhibitor subunit } 1 A(P P P 1 R 1 A) \\
\text { delivered via biological nanoparticle } \\
\text { technology }\end{array}$ & Congestive heart failure (CHF) & Preclinical \\
\hline
\end{tabular}




\section{ANALYSIS}

\section{TARGETS \& MECHANISMS}

researcher from the University of Washington Medical Center-tested the Ccna2 gene therapy in pig models of MI, which are more clinically relevant than murine species in terms of both size and cardiac genetics.

In the pigs, injection of the adenoviral vector encoding murine Ccna2 into cardiac tissue near the infarct site increased ejection fraction-a measure of cardiac function-at six weeks after treatment compared with baseline. The gene therapy also decreased cardiac fibrosis and increased the number of actively dividing cardiomyocytes compared with empty vector.

Next, the team examined heart tissue from the treated and control models for markers of stem cells or cardiac progenitor cells and found no differences between the two groups of animals. This indicated that the new cardiomyocytes in the treated models did not arise from stem or progenitor cells that had been recruited to the infarct site.

Lastly, video imaging experiments in primary pig cardiomyocytes

"This study addresses what I think is the most important question in cardiovascular medicine: can we get cardiomyocytes to divide?" - Hina Chaudhry, Icahn School of Medicine at Mount Sinai confirmed that the Ccna2 gene therapy induced mitosis.

Taken together, the findings showed that CCNA2 gene therapy could regenerate heart tissue and prevent fibrosis after MI by inducing existing cardiomyocytes to divide and repair the damage, the team wrote in its report in Science Translational Medicine.

"This study addresses what I think is the most important question in cardiovascular medicine: can we get cardiomyocytes to divide?" said Chaudhry, who founded VentriNova in 2006 to develop the CCNA2based technology.

The CCNA2 gene therapy could be more effective at treating MI than stem cell-based therapies, most of which have not resulted in significant or lasting improvements in cardiac function or shown evidence that the stem cells differentiated into cardiomyocytes, she said.

Chaudhry said that Columbia University holds a portfolio of patents-including at least three of which are issued-covering the CCNA2 gene therapy technology and its therapeutic applications, and Columbia has licensed the IP to VentriNova.

At least nine other companies have gene therapies in preclinical and clinical development to treat a range of cardiovascular indications, although none is intended to regenerate cardiac tissue and prevent fibrosis after MI (see Table 1, "Cardiovascular expressions").

\section{Division of labor}

VentriNova plans to examine tissue samples from the Science Translational Medicine study for any signs of Ccna2 activation in noncardiac tissues. Chaudhry does not expect to find any such signs because the adenoviral vector is replication deficient and thus cannot spread beyond the first cells it transfects.

Moreover, "we did not find evidence of Ccna2 activation in noncardiomyocyte cells, even within the heart tissue" of the pig models, she said.

Nevertheless, VentriNova has developed an adenoviral vector encoding human CCNA2 and a cardiac-specific promoter to avoid the potential for CCNA2 activation in noncardiac tissues, she said.

The company plans to begin IND-enabling studies of that product$\mathrm{VN}-100$ - in pig models of MI this year.

VentriNova is seeking investors for a series A round that would fund clinical development of the technology, Chaudhry said.

She added that her Mount Sinai team expects to publish a paper this year describing the mechanisms by which CCNA2 becomes silent after birth.

Haas, M.J. SciBX 7(9); doi:10.1038/scibx.2014.244

Published online March 6, 2014

\section{REFERENCES}

1. Shapiro, S.D. et al. Sci. Transl. Med.; published online Feb. 19, 2014; doi:10.1126/scitranslmed.3007668

Contact: Hina W. Chaudhry, Icahn School of Medicine at Mount Sinai, New York, N.Y. e-mail: hina.chaudhry@mssm.edu

2. Khan, R. \& Sheppard, R. Immunology 118, 10-24 (2006)

3. Sun, Y. Cardiovasc. Res. 81, 482-490 (2009)

4. Pagano, M. et al. EMBO J. 11, 961-971 (1992)

5. Sherr, C.J. \& Roberts, J.M. Genes Dev. 9, 1149-1163 (1995)

6. Yoshizumi, M. et al. J. Clin. Invest. 95, 2275-2280 (1995)

7. Bergmann, O. et al. Science 324, 98-102 (2009)

8. Kajstura, J. et al. Circulation 126, 1869-1881 (2012)

9. Chaudhry, H.W. et al. J. Biol. Chem. 279, 35858-35866 (2004)

10. Cheng, R.K. et al. Circ. Res. 100, 1741-1748 (2007)

11. Woo, Y.J. et al. Circulation 114, I206-I213 (2006)

\section{COMPANIES AND INSTITUTIONS MENTIONED}

Columbia University, New York, N.Y.

Columbia University Medical Center, New York, N.Y. Icahn School of Medicine at Mount Sinai, New York, N.Y. University of Washington Medical Center, Seattle, Wash. VentriNova Inc., New York, N.Y. 